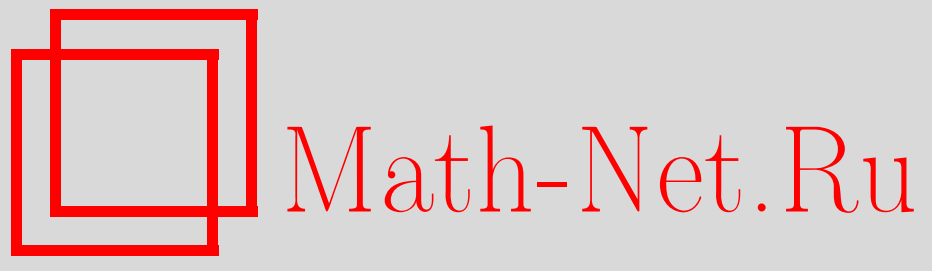

K 70-летию Александра Семеновича Холево, Теория вероятн. и ее примен., 2013, том 58, выпуск 4, 781

DOI: https://doi.org/10.4213/tvp4540

Использование Общероссийского математического портала Math-Net.Ru подразумевает, что вы прочитали и согласны с пользовательским соглашением http://www . mathnet.ru/rus/agreement

Параметры загрузки:

IP: 54.172 .240 .79

26 апреля 2023 г., $06: 32: 37$

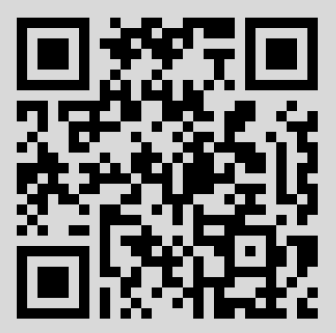


ТЕОРИЯ ВЕРОЯТНОСТЕЙ

Том 58

(c) $2013 \Gamma$.

\section{К 70-летию Александра Семеновича Холево}

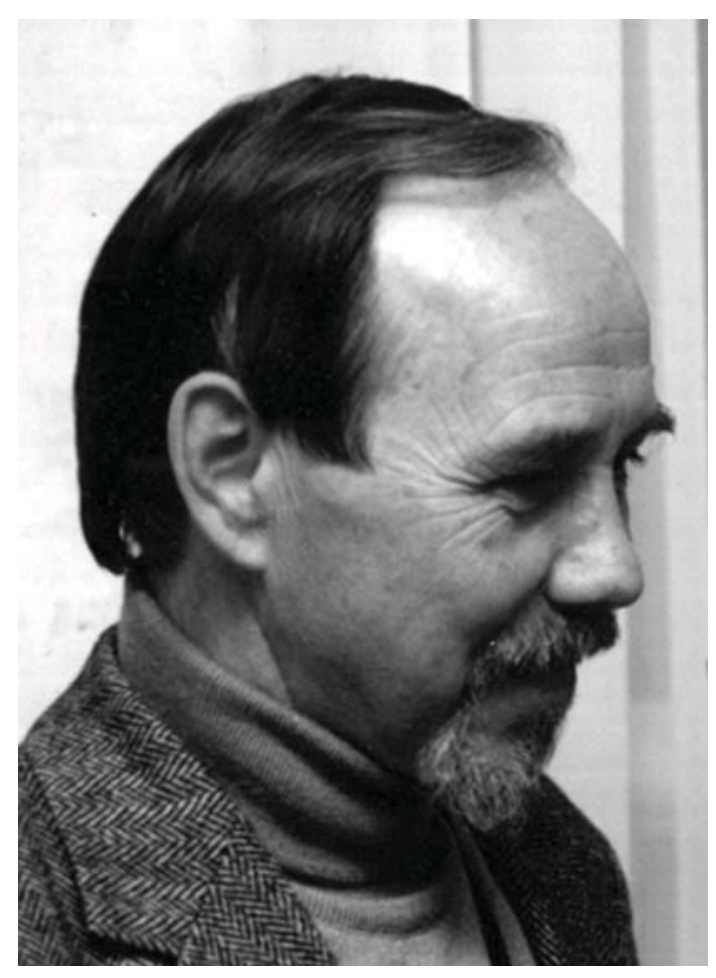

2 сентября 2013 года исполнилось 70 лет

доктору физико-математических наук, заведующему отделом теории вероятностей и математической статистики Математического института им. В. А. Стеклова РАН, заместителю главного редактора нашего журнала

\section{Александру Семеновичу Холево.}

Редакционная коллегия журнала «Теория вероятностей и ее применения» сердечно поздравляет Александра Семеновича с юбилеем и желает ему здоровья, благополучия и дальнейших научных достижений. 